\title{
Maximizing land productivity by diversified cropping systems with different nitrogen fertilizer types
}

\author{
Abd El-Hafeez A. ZOHRY ${ }^{1 *}$, Khadra A. ABBADY ${ }^{2}$, Enshrah I.M. EL-MAAZ ${ }^{2}$ and Hoda M.R.M. AHMED ${ }^{2}$ \\ Received February 16, 2017; accepted October 16, 2017. \\ Delo je prispelo 16. februarja 2017, sprejeto 16. oktobra 2017.
}

\begin{abstract}
Six field experiments were conducted in Giza Agricultural Research Station, Egypt during 2010, 2011 and 2012 growing seasons to study the effect of two types of $\mathrm{N}$ fertilizers (urea and urea form as slow-release (UF)) on intercropping cowpea with sunflower and intercropping wheat with pea. A split plot design with three replications was used. The results indicated that insignificant effect of cropping systems was found for sunflower and significant effect was found for cowpea yield. Significant effect of $\mathrm{N}$ fertilizers was found on sunflower and insignificant effect was found for cowpea yield. Furthermore, insignificant effect of interaction of cropping systems and $\mathrm{N}$ fertilizers was found for sunflower and significant effect was found for cowpea yield. With respect to wheat and pea intercropping, both crops were significantly affected by intercropping system. Significant effect of $\mathrm{N}$ fertilizers was found on wheat and insignificant effect was found for pea yield. Both wheat and pea were significantly affected by the interaction of cropping system and $\mathrm{N}$ fertilizers. Yield advantage was achieved because land equivalent ratio exceeded 1.00. Dominance analysis proved that leguminous crop is dominated component. Thus, the studied intercropping systems could be recommended to farmers due to its beneficial returns.
\end{abstract}

Key words: sunflower intercropped with cowpea; wheat intercropped with pea; urea; slow-release urea form; competitive relationships

\section{IZVLEČEK}

\section{MAKSIMIZIRANJE PRODUKTIVNOSTI ZEMLJIŠČ S POPESTRITVIJO KOLOBARJA Z MEDSETVIJO IN RAZLIČNIH NAČINOV GNOJENJA Z DUŠIKOVIMI GNOJILI}

\begin{abstract}
V šestih poljskih poskusih je bil preučevan učinek dveh načinov gnojenja $\mathrm{z}$ dušikovimi gnojili (urea in oblika ure $\mathrm{s}$ počasnim sproščanjem (UF)) na medsetev kitajske vinje $s$ sončnico in pšenice $\mathrm{z}$ grahom na Giza Agricultural Research Station, Egypt, v rastnih sezonah 2010, 2011 in 2012. Izveden je bil poskus z deljenkami s tremi ponovitvami. Rezultati so pokazali neznačilen vpliv kolobarja na pridelek pri sončnici in značilen učinek pri vinji. Značilen učinek dušikovih gnojil na pridelek je bil ugotovljen pri sončnici in neznačilen pri vinji. Še več, neznačilni učinek medsebojnega vpliva kolobarja in dušikovih gnojil je bil ugotovljen pri pridelku sončnice in značilen pri pridelku vinje. Pri medsetvi pšenice $\mathrm{z}$ grahom sta bili obe poljščini značilno vplivani $\mathrm{z}$ medsetvijo. Značilni učinek dušikovih gnojil je bil ugotovljen pri pridelku pšenice in neznačilen pri pridelku graha. $\mathrm{Na}$ pšenico in grah je značilno vplivala interakcija kolobarja in gnojenja z dušikom. Večji pridelek je bil dosežen pri kolobarjih z medsetvami, saj je bil ekvivalent zemljišča nad 1,00. Analiza dominance je pokazala, da so bile poljščine metuljnic prevladujoča komponenta. Preučevane kolobarje z medsetvami bi lahko priporočali kmetom zaradi ugodnih donosov.
\end{abstract}

Ključne besede: medsetev sončnic in kitajske vinje; medsetev pšenice in graha; urea; počasno sproščujoča urea; tekmovalna razmerja

\footnotetext{
1 Crop Intensification Research Department, Field Crops Research Institute, Agricultural Research Center, Egypt; *Corresponding author: abdelhafeezzohry@yahoo.com

2 Soils, Water and Environment Research Institute, Agricultural Research Center, Egypt
} 


\section{INTRODUCTION}

It is known that high population growth in Egypt is increasingly putting stress on environmental resources, particularly water resources, which limit our ability to cultivate new lands to fulfill food needs of the population. The traditional cultivation method done by the Egyptian farmers is two crops per year, namely winter crop followed by summer crop. However, the current food insecurity in Egypt motivates us to increase land productivity by intercropping. Intercropping is a useful technique to increase productivity per unit area, where one crop share its life cycle or part of it with another crop (Eskandari et al., 2010). This practice can be used as a way to improve soil fertility and increase land productivity (Kamel et al., 2010). The conventional ways for intensifying crop production are vertical and horizontal expansions (Andersen, 2005). Intercropping offers two additional dimensions, time and space. The intensification of land and resources use in space dimension is an important aspect of intercropping. It enhances the efficient use of light as two or more species that occupy the same land during a significant part of the growing season and have different pattern of foliage display (Francis, 1986). Furthermore, different rooting patterns can explore a greater total soil volume because of the roots being at different depths (Francis, 1986). These differences in foliage display and rooting patterns create the space dimension of intercropping (Dunn et al. 1999).

Intercropping cowpea with sunflower in Egypt can attain several befits, it can increase the cultivated area of summer forage crops, such as cowpea because in Egypt we have a gap between production and animal consumption of summer feed. This situation occurs there as competition between cereal crops and forage crops in the summer. Furthermore, there is another benefit for legume forage crop, it is expected that it will improve soil fertility (Hamd Alla et al., 2014). In addition, there was no previous research in Egypt on that intercropping system. Amujoyegbe et al., (2013) indicated that intercropping cowpea with sunflower did not affect sunflower yield, but it increased land equivalent ratio to be close to $200 \%$. Land equivalent ratio is the ratio of area needed under sole cropping to one of intercropping at the same management level to produce an equivalent yield. Rodrigues (2011) stated that, in cowpea intercropping with sunflower system, the highest productivity of sunflower occurred when cowpea planting density was $25 \%$.

Moreover, in Egypt, there is a large gap between production and consumption of wheat. Therefore, to increase its production, it can be intercropped with other crops, such as winter vegetables crops. Thus, intercropping wheat as a secondary crop with pea as the main crop will help in increasing wheat production on the national level.

Nitrogen is one of the most important mineral nutrients in crops production. The use of expensive chemical nitrogen fertilizers in Egypt is a limiting factor for lowincome farmers, which increases the cost of crop production. On the contrary, slow-release nitrogen fertilizers are effective and inexpensive alternative to soluble N (Jiao et al., 2005). Abbady et al., (2016) indicated that application of slow release nitrogen fertilizer increased the yield of pea intercropped with wheat.

Several researches were done in Egypt on the effect of intercropping systems in one growing season on land equivalent ratio. However, there was no previous research done on the effect of intercropping in two growing seasons on land equivalent ratio using different nitrogen fertilizers types. Thus, the objective of this research was to study the effect of two types of $\mathrm{N}$ fertilizers on intercropping cowpea with sunflower and intercropping wheat with pea to increase land productivity.

\section{MATERIALS AND METHODS}

The experiments were conducted at Giza Agricultural Research station, Giza, Egypt (latitude $=30.02^{\circ}$, longitude $=31.13^{\circ}$ and elevation above sea level $=22$, $5 \mathrm{~m})$. The soil of study site has been classified as clay.
Some mechanical and chemical properties have been recorded in Table 1 as described by Chapman and Pratt (1961). 
Table 1: Some mechanical and chemical characteristics of the studied soil.

\begin{tabular}{|c|c|c|c|c|}
\hline \multirow{2}{*}{$\begin{array}{l}\text { Depth } \\
\text { (cm) }\end{array}$} & \multicolumn{4}{|c|}{ Particle size distribution } \\
\hline & Sand (\%) & Silt (\%) & Clay (\%) & Texture \\
\hline $0-10$ & 7.50 & 37.00 & 55.50 & Loamy clay \\
\hline $10-30$ & 6.75 & 35.75 & 58.50 & Loamy clay \\
\hline $30-60$ & 5.50 & 36.50 & 59.00 & Loamy clay \\
\hline Depth & \multicolumn{4}{|c|}{ Chemical characteristics } \\
\hline$(\mathrm{cm})$ & $\mathrm{N}(\mathrm{mg} / \mathrm{kg})$ & O.M. (\%) & E.C. $(\mathrm{dS} / \mathrm{m})$ & $\mathrm{pH}$ \\
\hline $0-10$ & 55.50 & 2.10 & 1.11 & 7.11 \\
\hline $10-30$ & 53.50 & 1.80 & 1.25 & 7.30 \\
\hline $30-60$ & 53.60 & 1.77 & 1.21 & 7.11 \\
\hline Depth & \multicolumn{4}{|c|}{ Cations $(\mathrm{Me} / \mathrm{L})$} \\
\hline$(\mathrm{cm})$ & $\mathrm{K}^{+}$ & $\mathrm{Na}^{+}$ & $\mathrm{Mg}^{++}$ & $\mathrm{Ca}^{++}$ \\
\hline $0-10$ & 0.32 & 4.75 & 3.50 & 2.50 \\
\hline $10-30$ & 0.36 & 5.60 & 3.50 & 3.00 \\
\hline $30-60$ & 0.32 & 5.25 & 3.50 & 3.00 \\
\hline Depth & \multicolumn{4}{|c|}{ Anions $(\mathrm{Me} / \mathrm{L})$} \\
\hline$(\mathrm{cm})$ & $\mathrm{SO}_{4}^{--}$ & & & $\mathrm{HCO}_{3}^{-}$ \\
\hline $0-10$ & 4.07 & & & 0.50 \\
\hline $10-30$ & 4.46 & & & 0.50 \\
\hline $30-60$ & 4.07 & & & 0.50 \\
\hline
\end{tabular}

The experimental area has an arid climate with cool winters and hot dry summers. The meteorological variables were daily recorded throughout the crop growing season. Yearly average temperature was 25.8 , 26.4 and $25.2{ }^{\circ} \mathrm{C}$ for 2010,2011 and 2012 , respectively. Furthermore, rain was very low about $20 \mathrm{~mm}$ in the experimental site. The experiment has been initiated during the summer season for three consecutive years (2010 - 2013) with cowpea (Vigna unguiculata 'Karim 1 ') intercropped on sunflower (Helianthus annuиs 'Sakha 53') as summer pattern. It was followed by wheat (Triticum aestivum 'Sakha 94') intercropped with pea (Pisum sativum 'Master B') as winter pattern. The experimental design was split plot design with three replications. The experiment consisted of eight treatments as follows:

\subsection{Cropping systems (Figure 1)}

\subsubsection{Summer crops:}

2.1.1.1 Sunflower seeds were sown on both sides of bed $(120 \mathrm{~cm}$ width) with $100 \%$ planting density; meanwhile cowpea was drilled on middle of the same bed in two rows, with $20 \mathrm{~cm}$ distance (50\% of planting density). This pattern was expressed as $\mathrm{CS}_{1}$.

2.1.1.2 Sunflower seeds were grown on both sides of bed $(120 \mathrm{~cm}$ width) with $100 \%$ of planting density, meanwhile cowpea was drilled on middle of the same bed in three rows, with $20 \mathrm{~cm}$ distance $(75 \%$ of planting density). This pattern was expressed as $\mathrm{CS}_{2}$. 

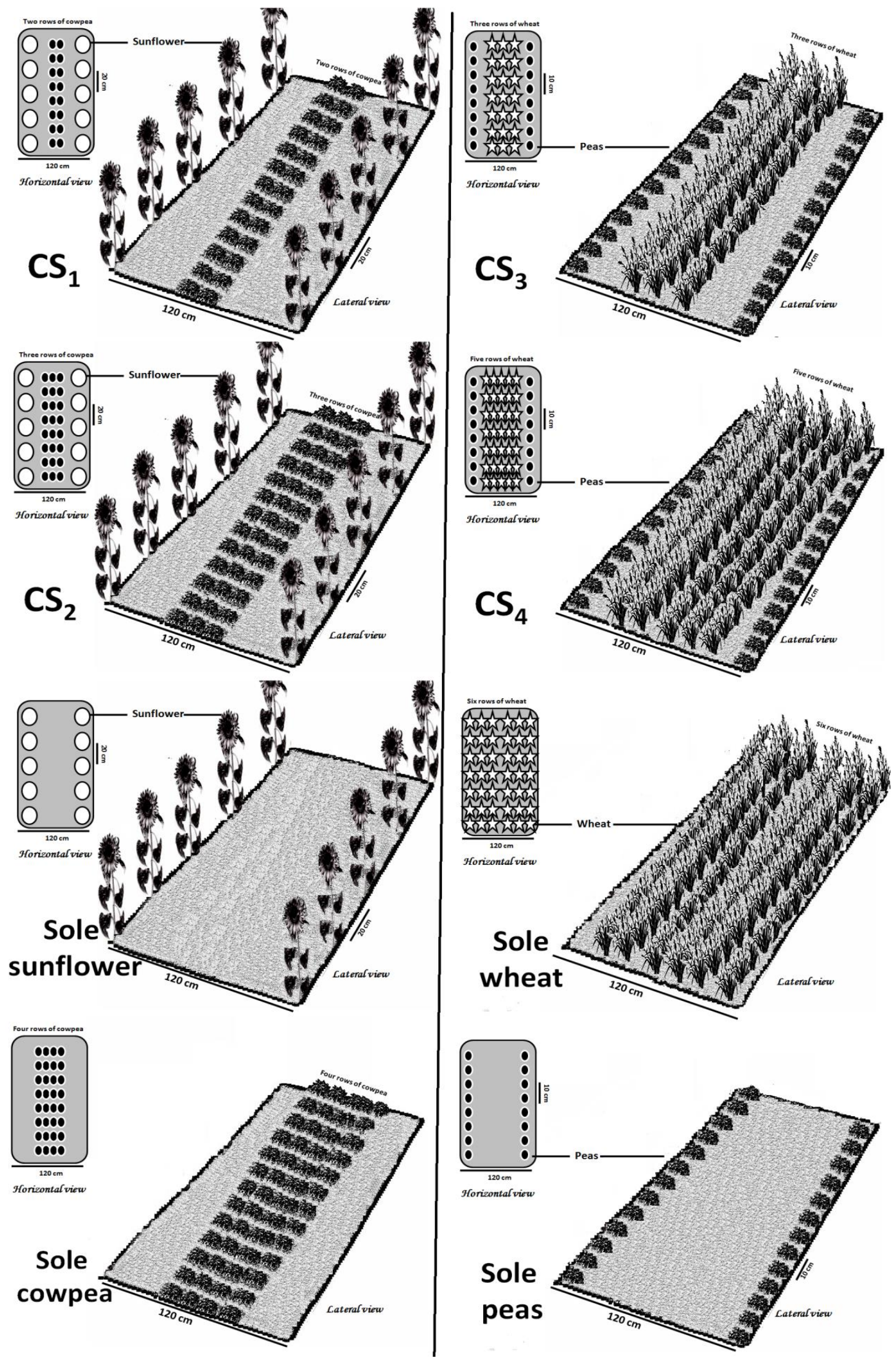

Figure 1: Intercropping and sole cultures of all the tested crops 
2.1.1.3 Cowpea seeds were drilled on middle of the bed (120 cm width) in four rows. This pattern was expressed as sole cowpea (100\% of planting density).

2.1.1.4 Sunflower seeds were grown on both sides of bed $(120 \mathrm{~cm}$ width). This pattern was expressed as sole sunflower (100\% of planting density).

\subsubsection{Winter crops}

2.1.2.1 Wheat grains were grown on middle of bed (120 cm width) in three rows (60\% of planting density), meanwhile pea was drilled on both sides of the same bed. This pattern was expressed as $\mathrm{CS}_{3}$.

2.1.2.2 Wheat grains were grown on middle of bed $(120 \mathrm{~cm}$ width) in five rows ( $80 \%$ of planting density), meanwhile pea was drilled on both sides of the same bed. This pattern was expressed as $\mathrm{CS}_{4}$.
2.1.2.3 Pea seeds were drilled on both sides of bed $(120 \mathrm{~cm}$ width). This pattern was expressed as sole pea (100\% of planting density).

2.1.2.4 Wheat grains were grown on middle of bed $(120 \mathrm{~cm}$ width) in six rows (100\% of planting density). This pattern was expressed as sole wheat.

\subsection{Nitrogen fertilizers}

\subsubsection{Urea as an ordinary fertilizer $(46.5 \% \mathrm{~N})$}

2.2.2 Urea form (UF) $(40 \% \mathrm{~N})$ as a slow-release fertilizer

Table 2 showed the applied amount of urea and urea form fertilizer during the three growing season (20102013) to the studied crops.

Table 2: Urea and urea form treatments applied to the studies crops in the three growing seasons

\begin{tabular}{lccc}
\hline Crop & Fertilizer type & $\begin{array}{c}\text { Application rate } \\
(\mathrm{kg} \mathrm{N} / \mathrm{ha})\end{array}$ & Application time \\
\hline Cowpea intercropped with sunflower & Urea & 142.8 & 3 doses every season \\
& Urea form & 238.0 & 1 dose every 2 seasons \\
Cowpea & Urea & 71.4 & 3 doses every season \\
& Urea form & 119.0 & 1 dose every 2 seasons \\
Sunflower & Urea & 71.4 & 3 doses every season \\
& Urea form & 119.0 & 1 dose every 2 seasons \\
Pea intercropped with wheat & Urea & 261.8 & 3 doses every season \\
\multirow{2}{*}{ Wheat } & Urea form & 0 & Not applied \\
& Urea & 166.6 & 3 doses every season \\
Pea & Urea form & 0 & Not applied \\
& Urea & 95.2 & 3 doses every season \\
& Urea form & 0 & Not applied \\
\hline
\end{tabular}

The experimental work has been managed adopting the permanent raised beds planting with reduced tillage (only hand weeding) in order to minimize disturbance of soil particles. On all crops in each treatment, recommended dosed of phosphorus and potassium fertilizers were added. The recommended dose of phosphorus was calcium super phosphate $\left(15.5 \% \mathrm{P}_{2} \mathrm{O}_{5}\right)$ with the amount of $240 \mathrm{~kg} / \mathrm{ha}$ added before sowing. Potassium sulphate $\left(48 \% \mathrm{~K}_{2} \mathrm{O}\right)$ was added at the rate 12 $\mathrm{kg} / \mathrm{ha}$ in two equal doses with first and second irrigation.

\subsection{Yield and its attributes}

At harvest, the following traits were measured on ten boarded plants from each plot.

\subsubsection{Summer season:}

Regarding to sunflower, plant height $(\mathrm{cm})$, head diameters $(\mathrm{cm})$, seed mass per head $(\mathrm{g})$, and seed yield ( $t /$ ha) were measured. Seeds yield was recorded on the basis of experimental plot area by harvesting all plants of each subplot. With respect to cowpea, forage yield ( $t /$ ha) was recorded on the basis of experimental plot area by harvesting all plants of each subplot.

\subsubsection{Winter season:}

For wheat, plant height $(\mathrm{cm})$, spike length $(\mathrm{cm}), 1000$ grain mass $(\mathrm{g})$, grain yield $(\mathrm{t} / \mathrm{ha})$ were measured. Yield was recorded on the basis of experimental plot area by harvesting all plants of each subplot. Regarding to peas, seed yield (t/ha) was recorded on the basis of experimental plot area by harvesting all plants of each subplot. 


\subsection{Competitive relationships}

\subsubsection{Land equivalent ratio (LER):}

It is defined as the ratio of area needed under sole cropping to one of intercropping at the same management level to produce an equivalent yield (Mead and Willey, 1980). It is calculated as follows:

$\mathrm{LER}=\left(\mathrm{Y}_{\mathrm{ab}} / \mathrm{Y}_{\mathrm{aa}}\right)+\left(\mathrm{Y}_{\mathrm{ba}} / \mathrm{Y}_{\mathrm{bb}}\right)$

Where: $\mathrm{Y}_{\mathrm{aa}}=$ pure stand yield of crop a (sunflower or wheat), $Y_{b b}=$ pure stand yield of crop $b$ (cowpea or pea), $\mathrm{Y}_{\mathrm{ab}}=$ intercrop yield of crop a (sunflower or wheat) and $\mathrm{Y}_{\mathrm{ba}}=$ intercrop yield of crop $\mathrm{b}$ (cowpea or pea).

\subsubsection{Aggressivity:}

It represents a simple measure of how much the relative yield increase in one crop is greater than the other in an intercropping system (Willey, 1979)

$A_{a b}=\left[Y_{a b} /\left(Y_{a a} \times Z_{a b}\right)\right]-\left[Y_{b a} /\left(Y_{b b} \times Z_{b a}\right)\right]$

$\mathrm{A}_{\mathrm{ba}}=\left[\mathrm{Y}_{\mathrm{ba}} /\left(\mathrm{Y}_{\mathrm{bb}} \times \mathrm{Z}_{\mathrm{ba}}\right)\right]-\left[\mathrm{Y}_{\mathrm{ab}} /\left(\mathrm{Y}_{\mathrm{aa}} \times \mathrm{Z}_{\mathrm{ab}}\right)\right]$

Where: $\mathrm{Y}_{\mathrm{aa}}=$ pure stand yield of crop a (sunflower or wheat), $\mathrm{Y}_{\mathrm{bb}}=$ pure stand yield of crop $\mathrm{b}$ (cowpea or pea), $Y_{a b}=$ intercrop yield of crop a (sunflower or wheat), $\mathrm{Y}_{\mathrm{ba}}=$ intercrop yield of crop $\mathrm{b}$ (cowpea or pea), $Z_{\mathrm{ab}}=$ The respective proportion of crop $\mathrm{a}$ in the intercropping system (sunflower or wheat), $\mathrm{Z}_{\mathrm{ba}}=$ the respective proportion of crop $b$ in the intercropping system (cowpea or pea).

Aggressivity determines the difference in competitive ability of the component crops in intercropping system. The positive sign of the equation results indicates which crop is dominant and the negative sign of the equation indicates which crop is the dominated component. Higher numerical values of aggressiveness denote greater difference in competitive ability, as well as, bigger difference between actual and expected yield in both crops.

\subsection{Statistical analysis}

Analysis of variance for split plot design for the obtained results of each season was performed. The homogeneity test was conducted of error mean squares and accordingly, the combined analysis of the three experimental summer and winter seasons carried out. The measured variables were analyzed by ANOVA using MSTATC statistical package (Freed, 1991). Mean comparisons were performed using the least significant differences (L.S.D) test with a significance level of $5 \%$ (Gomez and Gomez, 1984).

\section{RESULTS AND DISCUSSION}

\subsection{Yields of summer crops}

\subsubsection{Cropping systems}

The results in Table 3 indicated that all sunflower yield and attributes were not significantly affected by the cropping systems in the combined data across the three growing seasons. This result could be attributed to the high competitiveness of sunflower, as a tall crop on cowpea as short foliage plant.

Forage yield of cowpea (Table 3) was significantly affected by the cropping systems $(P \leq 0.05)$. Intercropping cowpea with sunflower decreased cowpea forage yield per unit area, compared to sole cowpea as a result of lower plant density in the intercropping system. As a result of intercropping, forage yield per area was decreased by $40 \%$, compared to sole cowpea. These results could be attributed to spatial arrangement of mixed pattern increased inter-specific competition between the intercrops for basic growth resources (Kumar et al., 1990).

With respect to plant density of intercropped cowpea, intercropping three rows of cowpea recorded higher forage yield than the other one (Table 3). Adjusting planting density is an important tool to optimize crop growth and the time required for canopy closure, and to achieve maximum biomass and yield (Liu et al., 2008). It was shown that increasing intercropped cowpea plant density from 50 to $75 \%$ of sole culture increased forage yield by $54 \%$ in the combined data across the three seasons $(P \leq 0.05)$. These results are in agreement with those obtained by Njoku and Muoneke (2008) who concluded that yield of cowpea was the highest with the highest cowpea density. 
Table 3: Effect of cowpea intercropping with sunflower system and $\mathrm{N}$ fertilizer type and their interaction on sunflower seed yield and its attributes and forage yield of cowpea, combined data (2010, 2011 and 2012)

\begin{tabular}{|c|c|c|c|c|c|c|c|c|}
\hline \multirow[t]{2}{*}{ Treatments } & $\mathrm{N}$ type & $\begin{array}{l}\text { Plant } \\
(\mathrm{cm})\end{array}$ & height & $\begin{array}{l}\text { Head diameter } \\
(\mathrm{cm})\end{array}$ & $\begin{array}{l}\text { Head seed } \\
\text { mass (g) }\end{array}$ & $\begin{array}{l}\text { Seed yield } \\
(\mathrm{t} / \mathrm{ha})\end{array}$ & $\begin{array}{l}\text { Cowpea } \\
\text { forage } \\
\text { (t/ha) }\end{array}$ & yield \\
\hline & Urea & 158.61 & & 16.88 & 64.76 & 3.61 & 21.77 & \\
\hline \multirow[t]{3}{*}{$\mathrm{CS}_{1}$} & UF & 160.92 & & 17.05 & 65.12 & 3.71 & 21.96 & \\
\hline & Average & 159.76 & & 16.96 & 64.94 & 3.66 & 21.86 & \\
\hline & Urea & 157.88 & & 17.53 & 65.35 & 3.59 & 33.60 & \\
\hline \multirow[t]{2}{*}{$\mathrm{CS}_{2}$} & UF & 159.02 & & 17.11 & 65.87 & 3.61 & 33.69 & \\
\hline & Average & 158.45 & & 17.32 & 65.61 & 3.60 & 33.64 & \\
\hline \multirow{4}{*}{$\begin{array}{l}\text { Average of } \\
\text { intercropping }\end{array}$} & Urea & 158.24 & & 17.20 & 65.05 & 3.60 & 27.68 & \\
\hline & UF & 159.97 & & 17.08 & 65.49 & 3.66 & 27.82 & \\
\hline & Average & 159.10 & & 17.14 & 65.27 & 3.63 & 27.75 & \\
\hline & Urea & 158.06 & & 17.72 & 65.19 & 3.58 & 46.24 & \\
\hline \multirow[t]{2}{*}{ Sole culture } & UF & 160.47 & & 17.66 & 65.52 & 3.72 & 46.20 & \\
\hline & Average & 159.26 & & 17.69 & 65.35 & 3.65 & 46.22 & \\
\hline \multirow{2}{*}{$\begin{array}{l}\text { Average of } \mathrm{N} \\
\text { fertilizer }\end{array}$} & Urea & 158.18 & & 17.37 & 65.10 & 3.59 & 33.87 & \\
\hline & UF & 160.13 & & 17.27 & 65.50 & 3.68 & 33.95 & \\
\hline \multicolumn{2}{|c|}{ LSD $_{0.05}$ Cropping systems } & N.S. & & N.S. & N.S. & N.S. & 8.38 & \\
\hline \multicolumn{2}{|c|}{$\mathrm{LSD}_{0.05} \mathrm{~N}$ fertilizer type } & N.S. & & N.S. & 0.39 & 0.06 & N.S. & \\
\hline \multicolumn{2}{|c|}{$\mathrm{LSD}_{0.05}$ Interaction } & N.S. & & N.S. & N.S. & N.S. & 10.44 & \\
\hline
\end{tabular}

\subsection{2 $\mathrm{N}$ fertilizer type}

Sunflower head seed mass per plant $(\mathrm{g})$ and seed yield $(\mathrm{t} / \mathrm{ha})$ were significantly affected by $\mathrm{N}$ fertilizer type, where $P \leq 0.05$ (Table 3). Sunflower plants had higher values of head seed mass and seed yield per hectare with the application of urea form as slow-release fertilizer, compared to those under the application of urea as ordinary fertilizer. Ahmed (1993) reported that urea form increased head diameter and head seed mass, compared to ordinary urea. Thus, it was likely that $\mathrm{N}$ in soil under ordinary fertilizer was not enough, which leaded to increase in blank seeds at the center of sunflower head (Sinwat and Streer, 1992). It is known that $\mathrm{N}$ from urea can be lost to the atmosphere, if urea remains on the soil surface for extended periods of time during warm weather (Overdahl et al., 2016), which could occurred during the summer season in the experiments. Moreover, urea form has a controlled release of $\mathrm{N}$ fertilizer that reduces $\mathrm{N}$ exposure to potential losses such as runoff, leaching and denitrification, compared to ordinary urea (Ruark, 2012). Similar resulted were observed by Abdel-Wahab and El Manzlawy (2016) who found that sunflower plants with the application of urea form reduced $\mathrm{N}$ losses as volatilization or leaching.

With respect to cowpea forage yield, it was not affected by $\mathrm{N}$ fertilizer type (Table 3) perhaps because of its symbiotic relationship with $\mathrm{N}$ fixing bacteria, which promoted plant growth and development (Amakiri, 2000).

\subsubsection{Interaction between cropping systems and $\mathrm{N}$ fertilizer type}

All the studied traits of sunflower were not significantly affected by the interaction between cropping systems and $\mathrm{N}$ fertilizer type (Table 3). These results revealed that each of these two factors act independently on sunflower yield and yield components meaning that cropping systems responded similarly to $\mathrm{N}$ fertilizer type for all the studied traits of sunflower.

With respect to cowpea crop, forage yield of cowpea was significantly affected by the interaction between 
cropping systems and $\mathrm{N}$ fertilizer type (Table 3). Intercropping two rows of cowpea with sunflower that received urea or urea form recorded lower forage yield per hectare than sole cowpea with the application of urea or urea form. Obviously, increasing plant density of intercropped cowpea crop from 50 to $75 \%$ of sole culture had a positive effect on forage yield per unit area, regardless of $\mathrm{N}$ fertilizer type. It is expected that application of urea negatively affected rhizobia activity in rhizosphere of cowpea roots, where growth of the bacteria that actually fix $\mathrm{N}$ and $\mathrm{N}$ fixing declined (Braunwart et al., 2001) although $\mathrm{N}$ fertilizer as starter could improve nodulation and biological $\mathrm{N}$ fixation capabilities. Hence, application of urea form may improve rhizobia activity and increase soil $\mathrm{N}$ availability for cowpea growth and development under cropping systems (Ali et al., 2010). These results show that there was a positive significant effect $(P \leq 0.05)$ of interaction of cropping systems and $\mathrm{N}$ fertilizer type on forage yield of cowpea.

\subsubsection{Cropping systems}

Wheat plant height $(\mathrm{cm})$, spike length $(\mathrm{cm}), 1000$-grain mass $(\mathrm{g})$ and grain yield $(\mathrm{t} / \mathrm{ha})$ were significantly affected by the cropping systems (Table 4). Conversely, intercropping culture significantly decreased plant height and grain yield per hectare, compared to sole wheat, which was decreased by $23 \%$. These results could be attributed to plant density of intercropped wheat plants of cropping systems $\mathrm{CS}_{3}$ and $\mathrm{CS}_{4}$ reached 60 and $80 \%$ of sole wheat, respectively, which, increased grain yield by $21 \%$ in the combined data across the three growing seasons $(P \leq 0.05)$.

With regard to pea crop, seed yield was significantly affected by the cropping systems in the combined data of the three seasons (Table 4). Seed yield was significantly increased by decreasing wheat plant density from 80 to $60 \%$ of sole wheat. These data may be due to intercropping pea with five rows of wheat affected negatively the ability of pea plants to intercept more solar radiation, compared to the other cropping system. It is important to mention that number of wheat rows per unit area could be related to the proportion of solar radiation that reaches pea plants by the distance between the two species during growth and development of pea plants.

\subsection{Yields of winter crops}

Table 4: Effect of wheat/peas intercropping and $\mathrm{N}$ fertilizer type and their interaction on wheat grain yield and its attributes and seed yield of peas, combined data across the three winter seasons (2010, 2011 and 2012)

\begin{tabular}{|c|c|c|c|c|c|c|}
\hline Treatments & N. type & $\begin{array}{l}\text { Plant height } \\
\text { (cm) }\end{array}$ & $\begin{array}{c}\text { Spike length } \\
(\mathrm{cm})\end{array}$ & $\begin{array}{c}\text { 1000-grain } \\
\text { mass (g) }\end{array}$ & $\begin{array}{l}\text { Wheat grain } \\
\text { yield/ha (t) }\end{array}$ & $\begin{array}{c}\text { Peas seed } \\
\text { yield/ha (t) }\end{array}$ \\
\hline \multirow{4}{*}{$\mathbf{C S}_{3}$} & Urea & 94.12 & 11.64 & 40.42 & 5.32 & 1.19 \\
\hline & UF & 95.31 & 11.79 & 41.05 & 5.90 & 1.15 \\
\hline & Average & 94.71 & 11.71 & 40.73 & 5.61 & 1.17 \\
\hline & Urea & 92.06 & 11.43 & 40.17 & 6.49 & 1.22 \\
\hline \multirow{2}{*}{$\mathbf{C S}_{4}$} & UF & 93.63 & 11.60 & 40.83 & 7.04 & 1.26 \\
\hline & Average & 92.84 & 11.51 & 40.50 & 6.76 & 1.24 \\
\hline \multirow{4}{*}{$\begin{array}{c}\text { Average of } \\
\text { intercropping }\end{array}$} & Urea & 93.09 & 11.53 & 40.29 & 5.90 & 1.20 \\
\hline & UF & 94.47 & 11.69 & 40.94 & 6.47 & 1.20 \\
\hline & Average & 93.78 & 11.61 & 40.61 & 6.18 & 1.20 \\
\hline & Urea & 95.66 & 11.20 & 38.89 & 7.81 & 2.23 \\
\hline \multirow[t]{2}{*}{ Sole culture } & UF & 97.11 & 11.36 & 39.31 & 8.30 & 2.30 \\
\hline & Average & 96.38 & 11.28 & 39.10 & 8.05 & 2.26 \\
\hline \multirow{2}{*}{$\begin{array}{c}\text { Average of } \mathbf{N} \\
\text { fertilizer }\end{array}$} & Urea & 93.94 & 11.42 & 39.82 & 6.54 & 1.54 \\
\hline & UF & 95.35 & 11.58 & 40.39 & 7.08 & 1.57 \\
\hline \multicolumn{2}{|c|}{ LSD $_{0.05}$ Cropping systems } & 1.69 & 0.18 & 0.17 & 1.05 & 0.61 \\
\hline \multicolumn{2}{|c|}{$\mathbf{L S D}_{0.05} \mathbf{N}$ fertilizer type } & 1.12 & 0.14 & 0.14 & 0.47 & N.S. \\
\hline \multicolumn{2}{|c|}{$\mathbf{L S D}_{0.05}$ Interaction } & 2.63 & N.S. & 0.25 & 1.19 & 0.75 \\
\hline
\end{tabular}




\subsection{2 $\mathrm{N}$ fertilizer type}

Wheat yield and its attributes were significantly affected by $\mathrm{N}$ fertilizer type, where it had higher values under urea form (Table 4). El-Kramany (2001) indicated that slow release of $\mathrm{N}$ fertilizer gave the highest 1000 -grain mass and grain yield of wheat per unit area. Furthermore, the long growing season of wheat caused great benefits from urea form than urea in the winter season. Nass and Reiser (1975) stated that urea form might facilitate the tillering ability of the plants, resulting in greater spike population than urea. Similar results were observed by Abdel-Wahab and El Manzlawy (2016) who reported that wheat plants with the application of urea form had higher values of wheat yield and its attributes.

With respect to pea crop, seed yield of peas was not affected by $\mathrm{N}$ fertilizer type (Table 3) as a result of being leguminous crop. Similar results were obtained by Sheha et al. (2015) who indicated that intercropped pea yield was not affected by mineral $\mathrm{N}$ fertilizer rates of wheat.

\subsubsection{Interaction between cropping systems and $\mathrm{N}$ fertilizer type}

All the studied traits of wheat were significantly affected by the interaction between cropping systems and $\mathrm{N}$ fertilizer type $(P \leq 0.05)$, except spike length (Table 4).
With respect to pea crop, seed yield of pea was significantly affected by the interaction between intercropping systems and the interaction between intercropping systems and $\mathrm{N}$ fertilizer type (Table 4). Intercropping peas with three rows of wheat, which received urea form recorded the highest seed yield $(P \leq 0.05)$. Rhizobia activity might be affected positively by application of urea form as ordinary fertilizer during the early growth stages of peas (Braunwart et al., 2001). These results showed that each of these two factors act dependently on seed yield of peas meaning that cropping systems responded differently to $\mathrm{N}$ fertilizer type for seed yield of pea $(P \leq 0.05)$.

\subsection{Competitive relationships}

\subsubsection{Land Equivalent Ratio (LER)}

The values of LER were estimated using data of recommended solid cultures of both crops. For the summer crops, intercropping cowpea with sunflower increased LER as compared to sole cultures of both crops in the combined data of the three seasons (Figure 2). It ranged from 1.47 when intercropping two rows of cowpea plants with sunflower under urea as ordinary fertilizer to 1.72 when intercropping three rows of cowpea with sunflower under urea or urea form.

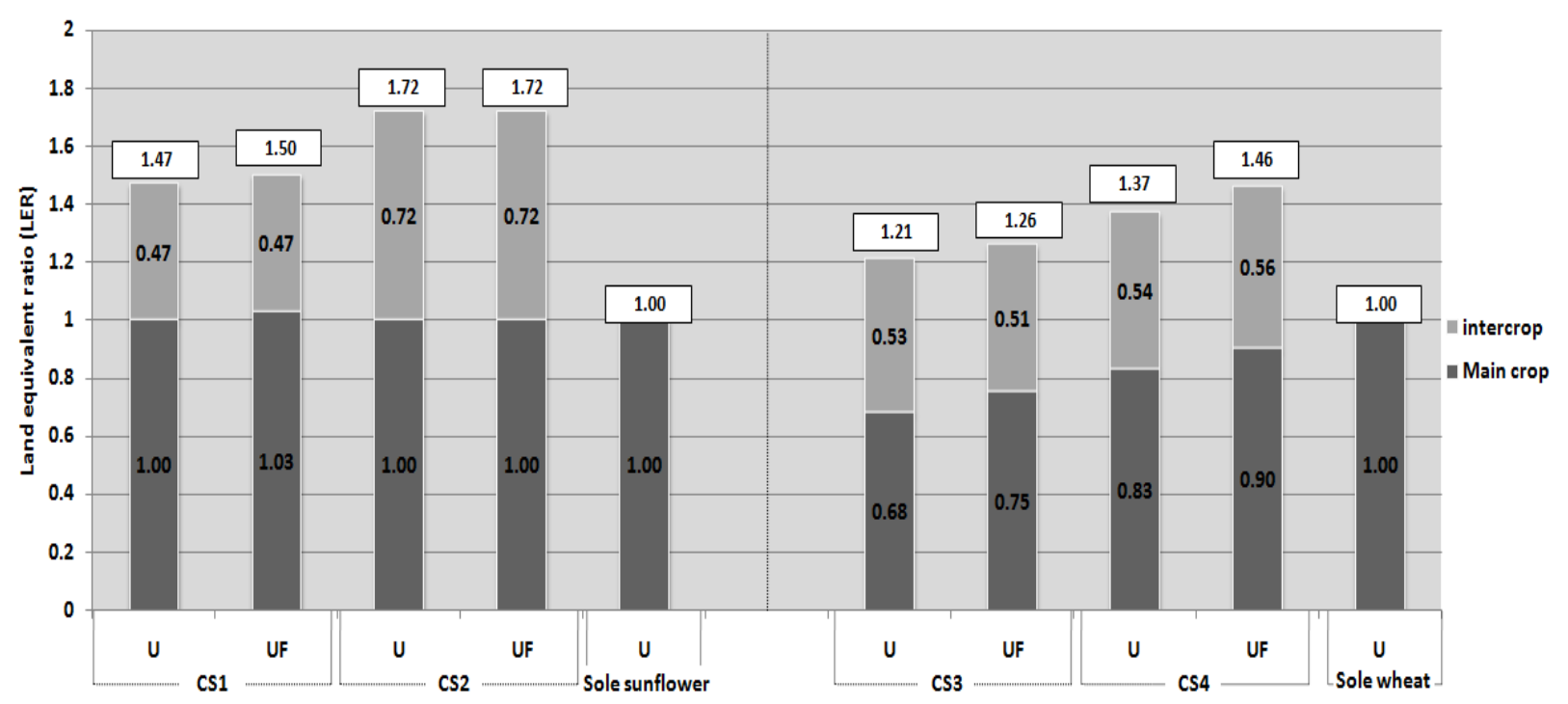

Figure 2: Land equivalent ratio (LER) as affected by intercropping culture, $\mathrm{N}$ fertilizer type and their interaction, combined data across the three seasons (2010, 2011 and 2012)

The advantage of the highest LER by intercropping three rows of cowpea with sunflower with the application of urea or urea form could decreased interspecific competition between the two species for basic growth resources, especially soil N. Obviously, increasing plant density of intercropped cowpea increased relative yield of cowpea. Consequently, LER 
depended on plant density of intercropped cowpea with regardless to $\mathrm{N}$ fertilizer type.

For the winter crops, intercropping peas with wheat increased LER, compared to sole cultures of both crops in the combined data of the three seasons (Figure 2). It ranged from 1.21 by intercropping peas with three rows of wheat plants with urea application as ordinary fertilizer to 1.46 by intercropping peas with five rows of wheat, which received urea form as slow release fertilizer. These results implied that LER depended on plant density of wheat with urea form under intercropping conditions.

\subsubsection{Aggressivity}

For the summer crops, the results indicate that the value of aggressivity of sunflower was positive for all treatments, while the values of aggressivity was negative for all intercropped cowpea with sunflower plants in the combined data of the three seasons (Table 5).

Table 5: Aggressivity as affected by intercropping culture, $\mathrm{N}$ fertilizer type and their interaction, combined data across the three seasons $(2010,2011$ and 2012)

\begin{tabular}{|c|c|c|c|}
\hline Treatments & N. type & Agg+ & Agg \\
\hline \multirow[t]{2}{*}{$\mathrm{CS}_{1}$} & Urea & +0.05 & -0.05 \\
\hline & UF & +0.08 & -0.08 \\
\hline \multirow[t]{2}{*}{$\mathbf{C S}_{2}$} & Urea & +0.03 & -0.03 \\
\hline & UF & +0.03 & -0.03 \\
\hline \multirow[t]{2}{*}{$\mathrm{CS}_{3}$} & Urea & +0.83 & -0.83 \\
\hline & UF & +1.00 & -1.00 \\
\hline \multirow[t]{2}{*}{$\mathrm{CS}_{4}$} & Urea & +0.45 & -0.45 \\
\hline & UF & +0.52 & -0.52 \\
\hline
\end{tabular}

These results showed that sunflower and cowpea plants are dominant and dominated components, respectively. In general, the interaction between $\mathrm{CS}_{1}$ and $\mathrm{CS}_{2}$, regardless to $\mathrm{N}$ fertilizer type tended to be having convergent values of the aggressivity. Accordingly, these results reveal that short growth duration of the intercrops played a major role in decreasing competitive pressure between them during the summer season.

For the winter crops, the results indicate that the value of aggressivity of wheat was positive for all the treatments, while, the values of aggressivity was negative for all intercropped peas with wheat plants in the combined data (Table 5). These data show that wheat and pea plants are dominant and dominated components, respectively. The highest negative values were obtained by intercropping peas with three rows of wheat which received urea form. Generally, there were wide range between aggressivity values of the interaction between cropping systems and $\mathrm{N}$ fertilizer type. These results reveal that number of wheat plants per unit area with regard to $\mathrm{N}$ fertilizer type seems to be determined competitive pressure between the intercrops during the winter season. Cereals were known to be more competitive for soil inorganic $\mathrm{N}$ than legumes at the beginning of crop growth (Naudin et al., 2010).

\section{CONCLUSION}

Our results revealed that diversified cropping system, namely cowpea intercropped with sunflower and wheat intercropped pea can have significant environmental benefits over the years. Slow release urea form has many beneficial effects over urea. Thus, the studied intercropping systems could be recommended to farmers due to its beneficial returns.

\section{REFERENCES}

Abbady, K.A., El-Maaz E.I.M., Ahmed H.M.R.M. and Zohry A.A. (2016). Carbon sequestration as a function of intercropping management practices and different nitrogenous fertilizer types. Journal of Soil Science and Agriculture Engeering, 7(8),565586.
Abdel-Wahab T.I., El Manzlawy Amal M. (2016).Yield and quality of intercropped wheat with faba bean under different wheat plant densities and slow release nitrogen fertilizer rates in sandy soil. American Journal of Experimental Agriculture, 11(6), 1-22. doi:10.9734/AJEA/2016/23895 
Ahmed Kh.A. (1993). Evaluation of efficiency of some $N$-slow release fertilizers under different rates of phosphatic fertilizers. Ph. D. Thesis, Faculty of Agriculture., Moshtohour, Benha Branch, Zagazig University, Egypt.

Ali Z., Khan H., Shah S.A., Ahmad I. (2010). Evaluation of leguminous forage crops for nodulation, nitrogen fixation and quality yield. American-Eurasian Journal of Agriculture and Environment Scince, 9(3);269-272.

Amakiri M.A. (2000). Microbes moving the world forward in the new millennium. Inaugural Lecture delivered on 29 Nov. 2000 at the Rivers State University Science and Technology, NkpoluOroworukwu, Port Harcourt, pp. 50-51.

Amujoyegbe B.J., Torimiro D.O., Tselaesele N., Balol T.V. (2013). On-farm evaluation of the productivity of intercropping sunflower with arable crops among smallholder farms in Nigeria and Botswana. African Journal of Agriculture Research, 8(16), 1553-1558. doi:10.5897/AJAR12.2000

Andersen M.K. (2005). Competition and complementarily in annual intercrops-the role of plant available nutrients. Ph.D. Thesis, Department of Soil Science, Royal Veterinary and Agricultural University, Copenhagen, Denmark. Sam funds litteraur Grafik, Frederiksberg, Copenhagen.

Braunwart K., Putnam D., Fohner G. (2001). Alternative annual forages - now and in the future. Proceeding ofthe $31^{\text {st }}$ California Alfalfa and Forage Symposium, Modesto, CA, UC Cooperative Extention. University of California, Davis. 95616.

Chapman H.D., Pratt P.E. (1961). Methods of Analysis for Soil, Plant and Water. Division of Agricultural Science, California University, U.S.A.

Dunn F., Williams J., Verberg K., Keating B.A. (1999). Can agricultural catchment emulate natural ecosystems in recharge control in southeastern Australia?. Agroforestry Systems, 45. 343-364. doi:10.1023/A:1006271805222

El-Kramany M.F. (2001). Effect of organic mature and slow-release $\mathrm{N}$-fertilizers on the productivity of wheat (Triticum aestivum L.) in sandy soil. Acta Agronomy Hungarica, 49, 379-385. doi:10.1556/AAgr.49.2001.4.9

Eskandari H., Ghanbari A., Javanmard A. (2009). Intercropping of cereals and legumes for forage production. Notulae Scientia Biologicae, 1: 07-13.

Francis C.A. (1986). Future perspectives of multiple cropping. pp. 351-370. In: C. A. Francis (eds.). Multiple Cropping Systems. Macmillan, New York.
Freed R.D. (1991). MSTATC Microcomputer Statistical Program. Michigan State University, East Lansing, Michigan, USA.

Gomez K.A., Gomez A.A. (1984). Statistical Procedures for Agricultural Research, $2^{\text {nd }}$ edition. John Willey and Sons, Toronto, ON, Canada.

HamdAlla W.A., Shalaby E.M., Dawood R.A., Zohry A.A. (2014). Effect of cowpea (Vigna unguiculata L.) with maize (Zea mays L.) intercropping on yield and its components. International Journal of Biosystem Engineering, 8(11),1200- 1206.

Liu X.B., Jin J., Wang G.H., Herbert S.J. (2008). Soybean yield physiology and development of high-yielding practices in Northeast China. Field Crops Research, 105,15. doi:10.1016/j.fcr.2007.09.003

Jiao X, Liang W, Chen L, Zhang H, Li Q, Wang P, Wen D. (2005). Effects of slow-release urea fertilizers on urease activity, microbial biomass, and nematode communities in an aquic brown soil. Science in China Series C Life Sciences, 48 (Suppl 1):26-32. doi:10.1007/BF02889798

Kamel A.S., El-Masry M.E., Khalil H.E. (2010). Productive sustainable rice based rotations in saline-sodic soils in Egypt. Egyptian Journal of Agronomy, 32(1):73-88.

Kumar S., Srivastave S., Panwar B. (1990). Intercropping of vegetables in spring planted sugarcane. Cooperative Sugar, 21(12),863-865.

Mead R., Willey R.W. (1980). The concept of a "land equivalent ratio" and advantages in yields from intercropping. Experimental Agriculture, 16: 21728. doi:10.1017/S0014479700010978

Nass H.G., Reiser B. (1975). Grain filling and grain yield relationships in spring wheat. Canadian Journal of Plant Science, 55, 673-678. doi:10.4141/cjps75-107

Naudin C., Corre-Hellou G., Pineau S., Crozat Y., Jeuffroy M.H. (2010).The effect of various dynamics of $\mathrm{N}$ availability on winter pea-wheat intercrops: crop growth, $\mathrm{N}$ partitioning and symbiotic $\mathrm{N}_{2}$ fixation. Field Crops Research, 119(1),2-11. doi:10.1016/j.fcr.2010.06.002

Njoku D.N., Muoneke C.O. (2008). Effect of cowpea planting density on growth, yield and productivity of component crops in cowpea/cassava intercropping system. Journal of Tropical Agriculture Food, Environment and Extension, 7(2), 106-113. doi:10.4314/as.v7i2.1591

Overdahl C.J., Rehm G.W., Meredith H.L. (2016). Fertilizer urea in: Nutrient Management. Minnesota Extension

Univ. 
Abd El-Hafeez A. ZOHRY et al.

http://www.extension.umn.edu/agriculture/nutrientmanagement /nitrogen/fertilizer-urea/.

Rodrigues C.D. (2011). System intercropped of sunflower string bean and peanuts in series replacement. M.Sc. Thesis, Universida de Federal do CearÃ.

Ruark M. (2012). Advantages and disadvantages of controlled-release fertilizers. Departement of Soil Science, WI FFVC, Wisconsin-Madison University.

Sheha A.M., Abdel-Wahab T.I., Abdel-Wahab Sh.I. (2015). Maximizing nitrogen and land use efficiencies of intercropped wheat with pea under different pea sowing dates. Journalof Plant Science, 3(6). 358 - 371.

Sinwat V., Streer B.T. (1992). Growth of flowers of sunflower in relation to their position in the capitulum shading and nitrogen supply. Field Crops Research, 34, 83-100. doi:10.1016/03784290(93)90113-2

Willey R.W. (1979). Intercropping its importance and research needs. Part I. Competition and yield advantage. Field Crops Abstract, 32, 1-10. 